\title{
PENGARUH GAYA KEPEMIMPINAN DAN BUDAYA ORGANISASI TERHADAP MOTIVASI DAN KOMITMEN ORGANISASI PADA UNIVERSITAS ALKHAIRAAT PALU
}

\author{
Ani Khuryatul Abadiyah, S.E.,MM \\ Dosen Fakultas Perikanan Universitas Alkhairaat
}

\begin{abstract}
ABSTRAK
Hasil penelitian ini, menemukan bahwa (a) gaya kepemimpinan, dan budaya organisasi berpengaruh positif dan signifikan terhadap motivasi kerja. Karena pentingnya Sumber Daya Manusia (SDM) dalam sebuah organisasi maka pemahaman konsep dan karakteristik SDM, khususnya yang berkaitan dengan gaya kepemimpinan, budaya organisasi, motivasi dan komitmen organisasi, harus dipahami oleh pengambil keputusan final. Dan informasi memiliki peranan yang sangat penting dalam bagi kepemimpinan, dan budaya organisasi, dan dampaknya terhadap motivasi dan komitmen organisasi sangat memegang peranan yang sangat penting, (b) gaya kepemimpinan,dan budaya organisasi berpengaruh positif dan signifikan terhadap komitmen organisasi, (c) motivasi berpengaruh positif dan signifikan terhadap komitmen organisasi, dan (d) gaya kepemimpinan, dan budaya organisasi berpengaruh positif dan signifikan terhadap komitmen organisasi melalui motivasi.
\end{abstract}

Kata kunci : Gaya kepemimpinan, Budaya organisasi, Motivasi dan Komitmen organisasi

\section{LATAR BELAKANG}

Sumber daya manusia merupakan salah satu unsur yang sangat menentukan keberhasilan suatu organisasi, disisi lain juga sebagai makhluk yang mempunyai pikiran, perasaan kebutuhan dan harapan harapan tertentu. Hal itu sangat memerlukan perhatian tersendiri karena faktor-faktor tersebut akan mempengaruhi prestasi, dedi- kasi dan loyalitas serta kecintaan terhadap pekerjaan dan organisasinya (Hasibuan, 2005). Menurut (Azis, 2019) Kelangsungan sebuah organisasi juga tak lepas pada kinerja pegawai yang baik dan kinerja pegawai yang baik juga berpengaruh dengan hasil kerja pegawai. Keadaan ini menjadikan sumber daya manusia sebagai aset yang harus ditingkatkan efisiensi dan produk motivitasnya. Untuk mencapai hal tersebut, maka suatu organisasi harus mampu menciptakan kondisi yang dapat mendorong dan memungkinkan karyawan untuk mengembangkan dan meningkatkan kemampuan serta ketrampilan yang dimiliki secara optimal. Menurut (Rahman, 2019) lingkungan kerja juga merupakan salah satu faktor yang menyebabkan peningkatan kinerja pegawai. Salah satu upaya yang dapat ditempuh oleh suatu organisasi untuk menciptakan kondisi tersebut adalah dengan menciptakan kondisi terhadap organisasi. Terkait masalah komitmen organisasi, pada beberapa unit kerja di Universitas Alkhairaat Palu sangat rendah baik dari tingkat manajemen maupun organisasi.

Diantaranya tidak patuh terhadap SOP, menolak nota dinas dari pimpinan dsb. Terjadinya penolakan dan ketidak patuhan terhadap manajemen dan organisasi itu berdasarkan survey awal salah satunya didorong oleh ketidak percayaan terhadap pim- pinan, tidak konsistennya aturan organisasi dll. Alasan berikutnya adalah rasa ketidaknyamanan dalam bekerja dikarenakan budaya kerja yang ada pada politekinik negeri Samarinda belum mampu memberikan ketenangan pegawai dalam bekerja. Selebihnya adalah karena alasan kesehatan, kesibukan diluar. Kurangnya komitmen pada Universitas Alkhairaat Palu tersebut sehingga menarik untuk dikaji lebih mendalam faktor-faktor penyeb berkurangnya komitmen organisasi. Manajemen sumber daya manusia adalah suatu proses menangani berbagai masalah pada ruang lingkup karyawan, pegawai, buruh, manajer dan tenaga kerja lainnya untuk dapat menunjang aktifitas organisasi atau perusahaan demi mencapai tujuan yang telah ditentukan. Bagian atau unit 
yang biasanya mengurusi sumber daya manusia adalah departemen sumber daya manusia atau dalam bahasa inggris disebut HRD atau human resource department. (Nanang Qosim, 2020)

Menurut A.F. Stoner manajemen sumber daya manusia adalah suatu prosedur yang berkelanjutan yang bertujuan untuk memasok suatu organisasi atau perusahaan dengan orangorang yang tepat untuk ditempatkan pada posisi dan jabatan yang tepat pada saat organisasi memerlukannya. Jika kepemimpinan transaksional mendasarkan diri pada prinsip pertukaran maka kepemimpinan transformasional (transformational leadership) berdasarkan prinsip pengembangan bawahan (follower development). Pemimpin transformasional mengevaluasi kemampuan dan potensi masing-masing bawahan untuk menjalankan suatu tugas/pekerjaan, sekaligus melihat kemungkinan untuk memperluas tanggung jawab dan kewenangan bawahan di masa mendatang. Sebaliknya, pemimpin transaksional memusatkan pada pencapaian tujuan atau sasaran, namun tidak berupaya mengembangkan tanggung jawab dan wewenang bawahan demi kemajuan bawahan. Perbedaan tersebut menyebabkan konsep kepemimpinan transaksional dan transformasional diposisikan pada satu kontinum dimana keduanya berada pada ujung yang berbeda (Dvir et.al., 2002).

\section{METODE PENELITIAN}

Penelitian menggunakan pendekatan kuantitatif dan berdasarkan jenis penelitian, maka penelitian ini merupakan penelitian yang menjelaskan hubungan kausal antara variabel atau yang disebut penelitian eksplanatori (explanatory research) yaitu penelitian untuk mengetahui dan menjelaskan pengaruh antar variabel yang ada dan dilanjutkan dengan pengujian hipotesis. Selain itu, penelitian ini termasuk dalam peneli- tian deskriptif, karena memberikan penjelasan secara deskriptif mengenai variabel- variabel yang hendak diteliti. Dalam penelitian ini akan dianalisis adalah pengaruh gaya kepemimpinan, kompensasi dan budaya organisasi terhadap motivasi dan komitmen organisasi.

\section{Populasi dan Sampel Penelitian}

Populasi penelitian ini adalah seluruh pegawai pada Universitas Alkhairaat Palu. Teknik pengambilan sampel yang digunakan dalam penelitian ini adalah purposive sampling yaitu pengambilan sampel berdasarkan pertimbangan atau kriteria tertentu sesuai dengan tujuan penelitian (Cooper dan Emory, 1997:245) dengan menggunakan teknik cross section. Adapun kriteria sampel yang digunakan adalah sebagai berikut : (a) pegawai yang telah bekerja minimum 3 tahun, (b) bukan pegawai outsourching atau kontrak.

\section{Hasil Penelitian}

Tabel 1. Nilai Koefisien Variabel Laten

\begin{tabular}{|c|c|l|l|l|l|l|c|}
\hline \multicolumn{2}{|c|}{} & Estimate & $\begin{array}{c}\text { Standardized } \\
\text { Coefficient }\end{array}$ & S.E. & C.R. & P \\
\hline Y1 & $<--$ & $\mathrm{X} 2$ & .520 & .716 & .054 & 9.684 & $* * *$ \\
\hline Y1 & $<---$ & $\mathrm{X} 1$ & .522 & .711 & .054 & 9.672 & $* * *$ \\
\hline Y2 & $<---$ & $\mathrm{Y} 1$ & -.956 & -.784 & 1.401 & -.682 & .495 \\
\hline Y2 & $<---$ & $\mathrm{X} 2$ & .959 & 1.083 & .733 & 1.308 & .191 \\
\hline Y2 & $<---$ & $\mathrm{X} 1$ & 1.125 & 1.258 & .743 & 1.514 & .130 \\
\hline
\end{tabular}

Berdasarkan Tabel 1, terdapat 5 hubungan, yaitu antara Gaya Kepemimpinan (X1), Budaya Organisasi (X2), Motivasi (Y1), dan Komitmen Organisasi (Y2).

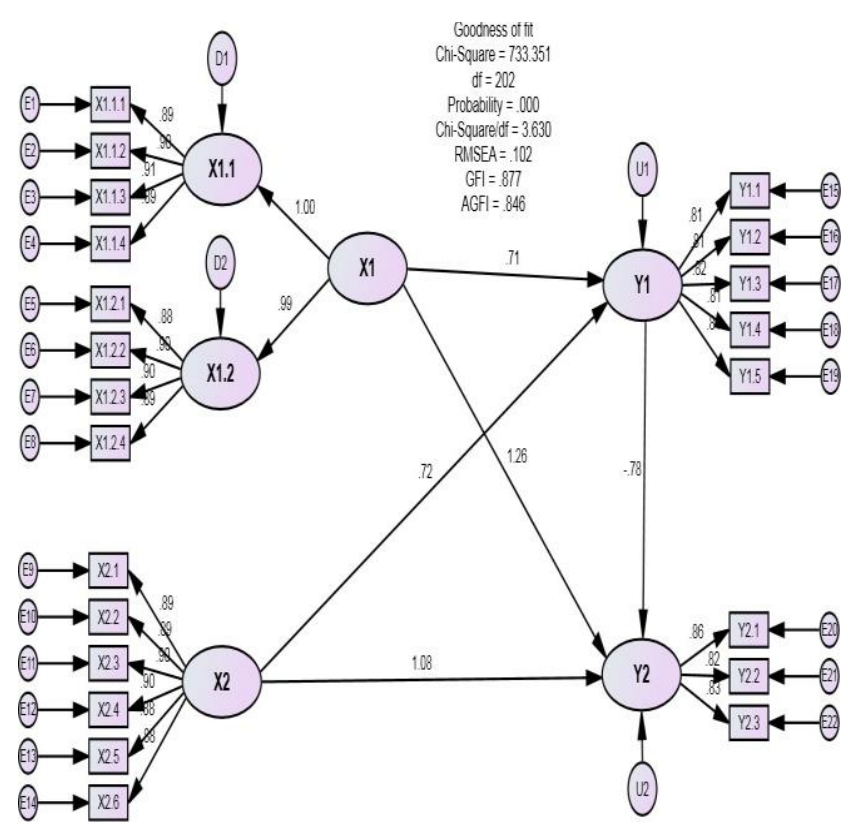

Gambar 1. Full Model Diagram Path

Berdasarkan uji kesesuaian model (fit model), diketahui bahwa model penelitian ini adalah fit 
karena memenuhi indeks pengujian berdasarkan rule of thumb yang disyarat- kan. Artinya, model tersebut secara empiric dapat diujikan yang digunakan dalam penelitian ini. Hasil rangkuman pengujian tertera pada Tabel 2 berikut

Tabel 2 Goodness of Fit Model

\begin{tabular}{|l|l|l|l|}
\hline $\begin{array}{c}\text { Goodness } \\
\text { of fit Index }\end{array}$ & Cut of value & \multicolumn{1}{|c|}{ Hasil } & \multicolumn{1}{|c|}{ Keterangan } \\
\hline Chi-Square & $<$ Chi-Sq 5\% & 733,351 & Model marjinal fit \\
\hline Probability & $>\mathbf{0 , 0 5 0}$ & $\mathbf{0 , 0 0 0}$ & Model marjinal fit \\
\hline CMIN/DF & $<2,000$ & 3,630 & Model marjinal fit \\
\hline RMSEA & $<0,080$ & 0,102 & Model marjinal fit \\
\hline GFI & $>0,900$ & 0,877 & Model marjinal fit \\
\hline AGFI & $>0,900$ & 0,846 & Model marjinal fit \\
\hline
\end{tabular}

Pada Tabel 2 didapatkan nilai Chi-Square hitung sebesar 733,351 dan nilai probabilitas 0,000 . Nilai Chi-Square tabel dengan derajat bebas 202 dan alpha 5\% adalah 236,159. Nilai Chi-Square hitung yang lebih besar dari nilai ChiSquare tabel $(733,351>236,159)$ atau nilai probabilitas yang lebih kecil dari alpha 5\% $(0,000<0,050)$ menyatakan bahwa hipotesis $\mathrm{H}_{0}$ ditolak yaitu matriks kovarians sampel berbeda secara signifikan dengan matriks kovarians estimasi atau dapat dikatakan bahwa model yang digunakan adalah kurang baik atau marjinal fit. Nilai RMSEA sebesr 0,102 lebih besar dari 0,080, dimana hal ini berarti bahwa model yang digunakan adalah marjinal fit atau kurang baik. Nilai

GFI sebesar 0,877 dan nilai AGFI sebesar 0,846 yang mendekati 0,900 menunjukkan bahwa model yang digunakan adalah model yang kurang baik atau marjinal fit.

\section{Analisis Hasil Uji Hipotesis}

Berdasarkan hasil uji statistik yang telah digunakan, semua hipotesis yang diujikan memenuhi persyaratan atau dapat digunakan sebagai model pengukuran dalam studi ini. Berdasarkan hasil pengujian hipotesis, disajikan hasil sebagai berikut.

Tabel 3. Pengujian Hipotesis Gaya Kepemimpinan (X1) terhadap Motivasi (Y1)

\begin{tabular}{|l|l|l|l|l|l|l|l|}
\hline \multicolumn{2}{|l|}{} & Estimate & $\begin{array}{c}\text { Standardized } \\
\text { Coefficient }\end{array}$ & S.E. & C.R. & P \\
\hline Y1 & $<--$ & X1 & .522 & .711 & .054 & 9.672 & $* * *$ \\
\hline
\end{tabular}

Dari hasil analisis diketahui terdapat hubungan yang positif dengan koefisien parameter $(0,522)$ dan signifikan antara Gaya Kepemimpinan (X1) terhadap Motivasi (Y1) karena memiliki nilai t statistik $(9,672)$ lebih besar dari nilai $\mathrm{t}$ tabel $(1,969)$, maka hipotesis $\mathrm{H}_{0}$ ditolak dan dapat disimpulkan bahwa terdapat pengaruh positif dan signifikan antara Gaya Kepemimpinan (X1) terhadap Motivasi (Y1) dengan toleransi kesalahan (alpha) sebesar 5\%. Arah hubungan positif menyatakan bahwa semakin tinggi Gaya Kepemimpinan (X1) maka akan meningkatkan Motivasi (Y1).

Tabel 4. Pengujian Hipotesis Budya Organisasi (X2) terhadap Motivasi (Y1)

\begin{tabular}{|c|c|c|c|c|c|c|c|}
\hline \multicolumn{2}{|c|}{} & Estimate & $\begin{array}{c}\text { Standardized } \\
\text { Coefficient }\end{array}$ & S.E. & C.R. & P \\
\hline Y1 & $<--$ & X2 & .520 & .716 & .054 & 9.684 & $* * *$ \\
\hline
\end{tabular}

Dari hasil analisis diketahui terdapat hubungan yang positif dengan koefisien parameter $(0,520)$ dan signifikan antara Budya Organisasi (X2) terhadap Motivasi (Y1) karena memiliki nilai $t$ statistik $(9,684)$ lebih besar dari nilai t tabel $(1,969)$, maka hipotesis $\mathrm{H}_{0}$ ditolak dan dapat disimpulkan bahwa terdapat pengaruh positif dan signifikan antara Budya Organisasi (X2) terhadap Motivasi (Y1) dengan toleransi kesalahan (alpha) sebesar 5\%. Arah hubungan positif menyatakan bahwa semakin tinggi Budya Organisasi (X2) maka akan meningkatkan Motivasi (Y1)

Tabel 5. Pengujian Hipotesis Gaya

Kepemimpinan (X1) terhadap Komitmen Organisasi (Y2)

\begin{tabular}{|c|c|l|l|l|c|c|c|}
\hline \multicolumn{2}{|l|}{} & Estimate & $\begin{array}{c}\text { Standardized } \\
\text { Coefficient }\end{array}$ & S.E. & C.R. & P \\
\hline Y2 & $<---$ & X1 & 1.125 & 1.258 & .743 & 1.514 & .130 \\
\hline
\end{tabular}

Dari hasil analisis diketahui terdapat hubungan yang positif dengan koefisien parameter $(1,125)$ namun tidak signifikan antara Gaya Kepemimpinan (X1) terhadap Komitmen Organisasi (Y2) karena memiliki nilai t statistik $(1,514)$ lebih kecil dari nilai $t$ tabel $(1,969)$, maka 
hipotesis $\mathrm{H}_{0}$ diterima dan dapat disimpulkan bahwa terdapat pengaruh positif namun tidak signifikan antara Gaya Kepemimpinan (X1) terhadap Komitmen Organisasi (Y2) dengan toleransi kesalahan (alpha) sebesar 5\%. Arah hubungan positif menyatakan bahwa semakin tinggi Gaya Kepemimpinan (X1) maka akan meningkatkan Komitmen Organisasi (Y2).

Tabel 6. Pengujian Hipotesis Budya Organisasi (X2) terhadap Komitmen Organisasi (Y2)

\begin{tabular}{|c|l|l|l|l|l|c|}
\hline \multicolumn{2}{|l|}{} & Estimate & $\begin{array}{c}\text { Standardized } \\
\text { Coefficient }\end{array}$ & S.E. & C.R. & P \\
\hline \hline--- & $\mathrm{X} 2$ & .959 & 1.083 & .733 & 1.308 & .191 \\
\hline
\end{tabular}

Dari hasil analisis diketahui terdapat hubungan yang positif dengan koefisien parameter $(0,959)$ namun tidak signifikan antara Budya Organisasi (X2) terhadap Komitmen Organisasi (Y2) karena memiliki nilai t statistik $(1,308)$ lebih kecil dari nilai t tabel $(1,969)$, maka hipotesis $\mathrm{H}_{0}$ diterima dan dapat disimpulkan bahwa terdapat pengaruh positif namun tidak signifikan antara Budya Organisasi (X2) terhadap Komitmen Organisasi (Y2) dengan toleransi kesalahan (alpha) sebesar 5\%. Arah hubungan positif menyatakan bahwa semakin tinggi Budya Organisasi (X2) maka akan meningkatkan Komitmen Organisasi (Y2).

\section{Tabel 7. Pengujian Hipotesis Motivasi (Y1) terhadap Komitmen Organisasi (Y2)}

\begin{tabular}{|c|c|c|c|c|c|c|}
\hline \multicolumn{2}{|c|}{ Keterangan } & Estimate & Standardized & S.E. & C.R. & $\mathbf{P}$ \\
\hline$<--$ & Y1 & -.956 & -.784 & 1.401 & .682 & .495 \\
\hline
\end{tabular}

Dari hasil analisis diketahui terdapat hubungan yang positif dengan koefisien parameter $(-0,956)$ namun tidak signifikan antara Motivasi (Y1) terhadap Komitmen Organisasi (Y2) karena memiliki nilai $\mathrm{t}$ statistik $(0,682)$ lebih kecil dari nilai $\mathrm{t}$ tabel $(1,969)$, maka hipotesis $\mathrm{H}_{0}$ diterima dan dapat disimpulkan bahwa terdapat pengaruh negatif namun tidak signifikan antara Motivasi (Y1) terhadap Komitmen Organisasi (Y2) dengan toleransi kesalahan (alpha) sebesar 5\%. Arah hubungan negatif menyatakan bahwa se- makin tinggi Motivasi (Y1) maka menurunkan Komitmen Organisasi (Y2).

\section{d. Pengaruh Langsung dan Pengaruh Tidak Langsung \\ Tabel 8. Hasil Pengaruh Langsung dan Pengaruh Tidak Langsung}

\begin{tabular}{|l|l|l|l|l|l|}
\hline \multirow{2}{*}{ Keterangan } & \multirow{2}{*}{$\begin{array}{c}\text { Variabel } \\
\text { Dipengaruhi }\end{array}$} & \multicolumn{4}{|c|}{ Variabel Asal } \\
\cline { 3 - 6 } & & $\mathrm{X} 1$ & $\mathrm{X} 2$ & $\mathrm{Y} 1$ & $\mathrm{Y} 2$ \\
\hline Pengaruh Langsung & $\mathrm{Y} 1$ & .711 & .716 & .000 & .000 \\
\cline { 2 - 6 } & $\mathrm{Y} 2$ & 1.258 & 1.083 & -.784 & .000 \\
\hline PengaruhTidak Langsung & $\mathrm{Y} 1$ & & & & \\
\cline { 2 - 6 } & $\mathrm{Y} 2$ & -.557 & -.561 & .000 & .000 \\
\hline Pengaruh Total & $\mathrm{Y} 1$ & .711 & .716 & .000 & .000 \\
\cline { 2 - 6 } & $\mathrm{Y} 2$ & .700 & .522 & -.784 & .000 \\
\hline
\end{tabular}

Tabel tersebut menjelaskan besarnya pengaruh langsung dan pengaruh tidak langsung pada model structural yang terbentuk. Pengaruh langsung yang terbentuk yaitu pada Gaya Kepemimpinan (X1) terhadap Motivasi (Y1) sebesar 0,711, Budaya Organisasi (X2) terhadap Motivasi (Y1) sebesar 0,716, Gaya Kepemimpinan (X1) terhadap Komitmen Organisasi (Y2) sebesar 1,258, Budaya Organisasi (X2) terhadap Komitmen Organisasi (Y2) sebesar 1,083, dan Motivasi (Y1) terhadap Komitmen Organisasi (Y2) sebesar -0,784.

Pengaruh tidak langsung yang terbentuk yaitu pada Gaya Kepemimpinan (X1) terhadap Komitmen Organisasi (Y2) sebesar-0,557, dan Budaya Organisasi (X2) ter- hadap Komitmen Organisasi (Y2) sebesar -0,561.

Pengaruh total yang terbentuk yaitu pada Gaya Kepemimpinan (X1) terhadap Motivasi (Y1) sebesar 0,711, Budaya Organisasi (X2) terhadap Motivasi (Y1) sebesar 0,716, Gaya Kepemimpinan (X1) terhadap Komitmen Organisasi (Y2) sebesar 0,700, Budaya Organisasi (X2) terhadap Komitmen Organisasi (Y2) sebesar 0,522, dan Motivasi (Y1) terhadap Komitmen Organisasi (Y2) sebesar -0,784.

Hasil penelitian ini, menemukan bahwa (a) gaya kepemimpinan, dan budaya organisasi berpengaruh positif dan signifikan terhadap motivasi kerja. Karena pentingnya Sumber Daya manusia (SDM) alam sebuah organisasi maka pemahamankonsep dan karakteristik SDM, khususnya yang berkaitan dengan gaya kepemimpinan, budaya organisasi, motivasi dan komitmen organisasi, harus dipahami oleh 
pengambil keputusan final. Dan informasi memiliki peranan yang sangat penting dalam bagi kepemimpinan, dan budaya organisasi, dan dampaknya terhadap motivasi dan komitmen organisasi sangat memegang peranan yang sangat penting, (b) gaya kepemimpinan,dan budaya organisasi berpengaruh positif dan signifikan terhadap komitmen organisasi, (c) motivasi berpengaruh positif dan signifikan terhadap komitmen organisasi, dan (d) gaya kepemimpinan, dan budaya organisasi berpengaruh positif dan signifikan terhadap komitmen organisasi melalui motivasi/

\section{KESIMPULAN DAN SARAN Kesimpulan}

Berdasarkan beberapa hasil yang diperoleh dari penelitian, maka disimpulkan beberapa hal, yaitu sebagai berikut: (1) Terbukti bahwa gaya kepemimpinan, dan budaya organisasi berpengaruh positif dan signifikan terhadap motivasi kerja. Karena pentingnya Sumber Daya Manusia (SDM) dalam sebuah organisasi maka pemahaman konsep dan karakteristik SDM, khususnya yang berkaitan dengan gaya kepemimpinan, budaya organisasi, motivasi dan komitmen organisasi, harus dipahami oleh pengambil keputusan final. Dan informasi memiliki peranan yang sangat penting dalam bagi kepemimpinan, dan budaya organisasi, dan dampaknya terhadap motivasi dan komitmen organisasi sangat memegang peranan yang sangat penting. (1) Terbukti pulah bahwa gaya kepemimpinan dan budaya organisasi berpengaruh positif dan signifikan terhadap komitmen organisasi. (2) Demikian pula motivasi berpengaruh positif dan signifikan terhadap komitmen organisasi. (3) Juga gaya kepemimpinan, dan budaya organisasi berpengaruh positif dan signifikan terhadap komitmen organisasi melalui motivasi.

\section{DAFTAR PUSTAKA}

Al-Meer, A. R. A. (1989). Organizational Commitment: A Comparison Of Westerners, Asians, And Saudis. International Studies Of Management \& Organization, 19, 74- 84.

Angel, H. L. Dan J. L. Perry, 1981. “An Empirical Assesment Of

Azis, A. (2019). Pengaruh Fasilitas, Kemampuan Dan Disiplin Kerja Terhadap Kinerja
Pegawai Kantor Kecamatan Tinombo Kabupaten Parigi Moutong. Jurnal Ekonomi Trend, 7(2), 30-41. Https://Doi.Org/10.31970/Trend.V7i2.178

Organizationalcommitment And Organizational Effectiveness" Administrative Science Quarterly 26.

Atkinson, J. (1964). An Introduction To Motivation. New Jersey: Van Nostrand Company, Inc. Avolio, B. J. \& Bass, B. M. (1987) Traditional Leadership : Charisma And Beyond. Ma, Livingstone Books.

Burns, James Macgregor. 1978. Transctional And Transformational Leadership, In: Hickman, Gill Robinson, Editor Leading Organizations; Perspectives For A New Era, Sage Publications, London

Bass, Bernard M, Avolio Bruce J, Jung, Dong, Dan Berson Yair (2003), Predicting Unit Performance By Assessing Transformational And Transactional Leadership. Woshingtong Dc.

Buchanan, B. (1975). Building Organizational Commitment: The Socialization Of Managers In Work Organizations. Administrative Science Quarterly, 19, 533546.

Chen, L. Y. (2004) Examining The Effect Of Organization Culture And Leadership Behaviors On Organizational Commitment, Job Satisfaction, And Job Performance At Small And Middle-Sized Firms Of Taiwan. The Journal Of American Academy Of Business, 432438.

Gasper, Joseph Mark (1992), Transformational Leadership : An Integrative Review Of The Literature (Leadership Research) (Dissertation), Unpublished, Western Michigan University, Usa

Ghozali, Imam. (2008). Structural Equation Modeling: Teori, Konsep, Dan Aplikasi Dengan Program Lisrel. Semarang: Badan Penerbit Universitas Diponogoro.

Hasibuan, Malayu S.P. 2006. Organisasi Dan Motivasi: Dasar Peningkatan Produktivitas. Jakarta : Bumi Aksara.

House, Robert J.; 1971. "A Path-Goal Theory Of Leader Effectiveness". Administrative Science Quarterly Vol.16: 321-339.

Kilmann, R.H., Saxton, M.J. And Serpa, R. (1986) Issues In Understanding And 


\section{Jumal ERonomi Trend Vol. 08 No. 02 Iufi-Desember 2020 E-ISSN. 2722-6565}

Changing Culture, California Yukl, Gary (1989), Kepemimpinan Dalam Management Review, 28, 2, 87-94

Langley, Thomas Clifford (1992), Concept And Styles of Leadership Asin The Performance Of The Property/Casuahry Insurance Industry (Casualty Insurance) (Dissertation). Unpublished, Golden Fate University.

Likert, R. (1967), New Patterns Of Management, Mc Graw-Hill Book Company, New York.

Locke, E. A. 1991, Toward A Theory Of Task Motivation And Incentive, Organizational Behavior And Human Performance, Mcgraw-Hill, Inc., New York

Luthan, Fred (1998), Organizational Behavior, (Seven Edition), Mcgraw-Hill, Inc., New York

Nurapiah, N., \& Qosim, N. (2020). Pengaruh Struktur Modal, Net Profit Margin, Return On Asset, Dan Return On Equity, Terhadap Nilai Perusahaan Pada Sektor Industri Makanan Dan Minuman Di Bursa Efek Indonesia. Jurnal Ekonomi Trend, 8(1), 35-40.

Nitisemito, Alex S. 2000. Management Personalia. Jakarta: Ghalia Indonesia. Pareek, Udai. 1985. Perilaku Organisasi. Jakarta: Pustaka Binaman Pressindo.

Pareke, Fahrudin Js. 2001. Jurnal Kepemimpinan Transformasional Dan Perilaku Kerja

Rahman, A. (2019). Pengaruh Hubungan Interpersonal, Lingkungan Kerja, Dan Kecerdasan Emosional Terhadap Kinerja Pegawai Pada Kantor Komisi Pemilihan Umum Daerah (Kpud) Kabupaten Parigi Moutong. Jurnal Ekonomi Trend, 7(1), 58-70.

Https://Doi.Org/10.31970/Trend.V7i1.17 3

Steers, Richard M, (1995) Efektivitas Organisasi, Terjemahan Cetakan Kedua, Ali Bahasa Magdalena Jamin, Erlangga Jakarta.

Sugiyono, (2002). Metode Penelitian Bisnis, Alfabeta Cv, Bandung.

Yousef, A. D. 2000. Organizational Commitment: A Mediator of Therelationships of Leadership Behavior With Job Satisfaction And Performancein A NonWestern Country, Journal Of Management Psychology. Vol 15 No. 1, 2000, Pp. 6-28. 